\title{
The Right to Property as Regional Custom in Europe
}

\author{
Dr Lisa Mardikian
}

\begin{abstract}
The article examines the right to property in Europe and elaborates its content, with a view to developing a better understanding of the legal nature and scope of its protection. It is argued that an obligation to protect the right binds states in Europe under regional customary law on the basis of clear evidence of state practice and opinio juris that support the emergence of such an obligation. To illustrate this, the article initially explores the substantive standards of protection of the right under conditions of pluralism, taking into account the case law of the European Court of Human Rights and the Court of Justice of the European Union. Subsequently, the focus is placed on regional practice with a psychological element of conviction on the existence of legal obligation to protect the right to property in order to shed light on the emergence of a regional customary norm.
\end{abstract}

Keywords: right to property; regional customary law; European Court of Human Rights; good governance; international peace

\section{Introduction}

The inclusion of the right to private property in the European Convention on Human Rights (ECHR) under Article 1 of Protocol No 1 (A1-P1) was a progressive development towards promoting economic freedom within a regional system of human rights protection. Despite this, international lawyers have not often paid attention to the development of the right to property, its nature and key elements of its content in the European public order. Some have placed the primary focus on the case law of the European Court of Human Rights (ECtHR or Court) dealing with restitution claims in the context of transition from centrally planned to 
open market economies in Eastern European states. ${ }^{1}$ Given that the scale of interference with private property by the previous regime has been extensive, emergence from an authoritarian system of governance entails comprehensive legislative and institutional reform to establish a human rights order and to promote the rule of law. In light of this, the Court has been criticised for its reluctance to examine cases of abuses of the right to property committed by the former communist regime before the state's accession to the Convention by excluding them from the scope of its temporal jurisdiction. ${ }^{2}$ The Court has instead examined disputed violations of the right to property under A1-P1 which occurred after the state had joined the ECHR or where the violation predated the state's acceptance of the Court's jurisdiction but its effects had been of a continuous nature. ${ }^{3}$ These commentators would favour a more robust approach by the ECtHR to correct abuses that occurred in the past with a view to contributing to the transition to a new legal and social order. Others have questioned the extent to which substantive standards for the protection of the right can and should be developed beyond the state, given that regulation of property is deeply entangled with social and economic principles in the domestic sphere. From this perspective, the regulation of property is contextspecific and therefore the development of a common set of principles would be of little value or not viable. ${ }^{4}$ With a diversity of views on the desirability and viability of the right at a regional level, a closer analysis of the legal mechanisms surrounding it is necessary.

The objective of this article is to examine the right to property in Europe and to elaborate its content, with a view to providing an in-depth understanding on the legal nature and scope

\footnotetext{
${ }^{1}$ James A Sweeney, The European Court of Human Rights in the Post-Cold War Era: Universality in Transition (Routledge, 2013); Antoine Buyse and Michael Hamilton (ed), Transitional Jurisprudence and the ECHR: Justice, Politics and Rights (CUP, 2011) 12.

${ }^{2}$ Tom Allen, 'Restitution and Transitional Justice in the European Court of Human Rights' (2006) 13 Columbia Journal of European Law 1, 22; Patrick Macklem, 'Rybná 9, Praha 1: Restitution and Memory in International Human Rights Law' (2005) 16 European Journal of International Law 1, 8; Aeyal M Gross, 'Reinforcing the New Democracies: The European Convention on Human Rights and the Former Communist Countries - A Study of the Case Law' (1996) 7 European Journal of International Law 89, 90.

${ }^{3}$ Compare for example: Malhous $v$ The Czech Republic (Grand Chamber Decision as to the Admissibility), Application No 33071/96, Judgment of 13 December 2000; Case of Papamichalopoulos and Others v Greece, Application No 14556/89, Judgment of 24 June 1993; Case of Loizidou v Turkey, Application No 15318/89, Judgment of 18 December 1996.

${ }^{4}$ Tim Hayward, 'Human Rights vs Property Rights' (2013) Just World Institute Working Paper 2013/04.
} 
of its protection. The argument put forward is that an obligation to protect the right to property binds states in Europe under regional customary law on the basis of clear evidence of state practice and opinio juris that support the emergence of such an obligation. The working hypothesis for this article is that the protection of the right to property in Europe is derived from a variety of legal sources which, through their coordination, achieve to build a system of protection with distinct pluralistic characteristics. ${ }^{5}$ As the ECtHR interprets the right to property under the Convention, it develops interpretive tools that underline and guide the articulation and application of the right in concrete cases. Such tools enable the ECtHR to operate in a complex web of interactions with international law as well as domestic legislation on property rights, which is situated within the differentiated economic structures of the contracting parties, and to mediate conflicts between competing understandings of the social value of property. In doing so, the Court achieves to manage the differences in the application of the right in domestic settings by indicating broadly defined procedural standards and objectives that provide opportunities for upholding the right in a pluralistic legal landscape. In this sense, it will be shown that the conceptualisation of the right is intertwined, even though in varying degrees, with standards of good governance, the facilitation of transnational economic activities and the restoration of international peace. They constitute three core features which underpin judicial interpretation and steer a pluralist articulation of the right.

The ECtHR has played a central role in clarifying and substantiating the content of the right to property. Its rich jurisprudence on A1-P1 has sent strong signals that a state eroding the protection of the right appears to risk not only the violation of its obligations under the Convention, but also to undermine the effectiveness and good governance of the domestic legal framework. Indeed, the Court has made a clear link between the protection of the right, the establishment of the rule of law and stability in property relations and has therefore placed

\footnotetext{
${ }^{5}$ See Neil Walker, Intimations of Global Law (CUP, 2015); Nico Krisch, Beyond Constitutionalism: The Pluralist Structure of Postnational Law (OUP, 2011).
} 
the right to property as a cornerstone in a democratic and peaceful European public order. These developments merit a closer analysis in order to illustrate the growing importance of the Court's jurisprudence in interpreting the right.

At the same time however, an analysis should not neglect the contribution that other regional actors have made to the development of the right. Thus, the jurisprudence of the Court of Justice of the European Union (CJEU) and the practice of regional institutions such as the Organisation for Security and Co-operation in Europe (OSCE) should be considered as pertinent in forming a system of protection for the right to property and in facilitating the evolution and application of the relevant law. These sources of authority interact and co-exist side by side, feeding into the system of protection of the right to property in Europe, and therefore are significant for a close examination of the right. They offer supplementary elements of the protection of the right outside the scope of the Convention system, but within the geographical area of Europe. As will be illustrated, they contribute to the emergence of wider patterns and evidence of legal practice that lead to the conclusion that the right to property has developed into a regional customary norm.

In light of this, the argument is developed as follows. In section II, significant aspects of the ECHR system that can lead to establishment of custom will be explored. The aim is to highlight that a close examination of the dynamic interpretation of the Convention reveals that relevant state practice and opinio juris can be generated and evolve within the ECHR so as to enable the emergence of a right as regional custom. In section III, the jurisprudence of the ECtHR is explored in order to shed light on the core content of the right in Europe. This is especially pertinent because the right to property under the ECHR has not been adequately analysed when compared to civil and political rights under the Convention. Key principles that define the content of the right are explored, with particular emphasis on the payment of full or partial compensation in cases of interference with the right to property owned by 
nationals, the provision of full compensation following the interference of property belonging to foreign nationals and the right of internally displaced persons (IDPs) and refugees to restitution of property or, where not possible, to receive compensation. The analysis is selective and deals with central aspects of legal protection that demonstrate how the right is linked with a plurality of legal principles and regional legal systems in Europe. ${ }^{6}$ While the discussion is centred on the case law of the ECtHR, EU and international rules are also considered where appropriate. The analysis draws on case law of the CJEU and the International Court of Justice (ICJ) to illustrate common threads, but also some inconsistencies, in the protection of the right as indicated in the jurisprudence of different courts. In section IV, the legal nature of the right to property in Europe is identified, and the discussion reveals that the obligation to protect the right has developed into a regional customary rule on the basis of evidence of regional practice with a psychological element of conviction on the existence of a legal obligation to protect the right.

\section{The ECHR and Regional Custom}

To answer the question whether the right to property has developed into regional custom, it is first necessary to have a grasp of the key elements of the ECHR that can contribute to the development of customary rules. The main point of departure is that the ECHR system provides strong evidential value for ascertaining the generation of regional custom, which is manifested in the jurisprudence of the Court and, in particular, the evolutive/dynamic method of interpretation that it has adopted. Despite the fact that the right has been enshrined in A1$\mathrm{P} 1$ of the Convention and is binding as such on contracting parties, this in itself should not render the enquiry moot. As the International Law Commission (ILC) has confirmed, it is

\footnotetext{
${ }^{6}$ For instance, the evolving association between the right to property and social security in the jurisprudence of the ECtHR is a significant point of enquiry, but falls outside the scope of this discussion. See: Aiofe Nolan, Rory O'Connell, Colin Harvey, Human Rights and Public Finance: Budgets and the Promotion of Economic and Social Rights (Hart Publishing, 2014). 
clear that treaties give 'rise to a general practice that is accepted as law (opinio juris) ${ }^{,}{ }^{7}$ thus contributing to the emergence of a new rule of customary international law. Provided that a rule embodied in a treaty also finds support in external instances of practice coupled with acceptance as a legal obligation, then it can be established as a regional customary norm. ${ }^{8}$ The enquiry is particularly important in the context of the right to property because its status and substantive content under general international law have not been settled and remain unclear. Property rights are protected in diverse areas of transnational law, such as trade and investment law, intellectual property law and commercial law. Yet, the absence of the right from the 1966 Human Rights Covenants and the ambiguity in the relevant case law of the ICJ discussed in section III below have contributed to this uncertainty. Therefore, it is necessary to shed light on how relevant practice and opinio juris have evolved in Europe within and outside the Convention system and to demonstrate the emergence of a customary rule.

The Court has consistently held that the Convention does not simply impose reciprocal rights and obligations in pursuance of the individual national interests of the member states, but seeks to establish a common public order in Europe. ${ }^{9}$ In this sense, the Convention represents both state and non-state actors and is part of a "pluriverse" ${ }^{10}$ of legal sources of authority that involves the interaction of regional treaty law, national constitutional law and international law. The judgments of the Court contribute to building a 'Europe-wide human rights jurisprudence', ${ }^{11}$ with the aim to further realise human rights in the context of democratic governance and the rule of law and in accordance with the intentions of the

\footnotetext{
${ }^{7}$ ILC, 'Identification of Customary International Law' Sixty-eighth Session (2 May-10 June and 4 July-12 August 2016) UN Doc A/71/10 Conclusion 11; See: Tulio Treves, 'Customary International Law', in Rüdiger Wolfrum (ed), Max Planck Encyclopedia of PIL (OUP 2010).

${ }^{8}$ Michael Wood, 'Third Report on Identification of Customary International Law' Sixty-seventh session (27 March 2015) UN Doc A/CN.4/682 at 18.

${ }^{9}$ See: Case of Austria v Italy, Application no 788/60, Judgment of 11 January 1961; Case of Ireland v the United Kingdom, Application no 5310/71, Judgment of 18 January 1978; Case of Cyprus v Turkey, Application No 25781/94, Judgment of 10 May 2001; Andrea Bianchi, 'Globalisation of Human Rights: the Role of Non-State Actors' in Gunther Teubner (ed), Global Law without a State (Aldershot, 1997) 179, 190.

${ }^{10}$ Armin von Bogdandy and Jürgen Bast (ed), Principles of European Constitutional Law, (2 ${ }^{\text {nd }}$ edn, Hart Publishing, 2011) 3; See: Nico Krisch, 'The Open Architecture of European Human Rights Law' (2008) 71 Modern Law Review 183.

${ }^{11}$ Luzius Wildhaber, 'A Constitutional Future for the European Court of Human Rights' (2002) 23 Human Rights Law Journal 161, 163.
} 
contracting parties as expressed in the Preamble of the Convention. ${ }^{12}$ To achieve this purpose, the ECtHR has endorsed the principle of evolutive interpretation. It allows the Court to determine the meaning of the Convention in the light of significant developments in the political and social attitudes of the contracting parties and to reflect changes in the societal values that modern legal systems share. ${ }^{13}$ By reflecting the idea that the Convention is a 'living' instrument, this method of interpretation leads to the 'practical and effective' protection of the rights and ensures their necessary progressive development.

Subsequent agreements and practice provide central elements in determining whether the meaning of a term in a treaty is capable of evolving over time, and the ILC has singled out the approach of the ECtHR for taking a broad view in engaging with evidence that lead to dynamic interpretation. ${ }^{14}$ In particular, it has pointed out that such interpretation by the Court is 'regularly supported by an elaborate account' of subsequent state, social and international legal practice. ${ }^{15}$ Significantly therefore, the common position of domestic legal systems as well as international rules, judgments of international courts and soft law international documents are not directly related to the application of the Convention, but have proven crucial in the identification of a certain degree of convergence in the practice of the states and the affirmation of European-wide practice and consensus. For example, the ECtHR has considered, among others, resolutions of the Parliamentary Assembly, ${ }^{16}$ recommendations of the Council of Ministers, ${ }^{17}$ the International Labour Organisation Convention on Forced

\footnotetext{
${ }^{12}$ See: Eirik Bjorge, The Evolutionary Interpretation of Treaties (OUP 2015); Vassilis Tzevelekos and Kanstantsin Dzehtsiarou, 'International Custom Making and the ECtHR's European Consensus Method of Interpretation' (forthcoming) 3 and 11.

${ }^{13}$ Christian Djeffal, 'Dynamic and Evolutive Interpretation of the ECHR by Domestic Courts? An Inquiry into the Judicial Architecture of Europe' in Helmut Philipp Aust and Georg Nolte (eds), The Interpretation of International Law by Domestic Courts: Uniformity, Diversity, Convergence' (OUP, 2016) 175; See: Case of Tyrer v The United Kingdom, Application No 5856/72, Judgment of 25 April 1978; Case of Christine Goodwin v The United Kingdom, Application No 28957/95, Judgment of 11 July 2002.

${ }^{14}$ ILC, 'Subsequent Agreements and Subsequent Practice in Relation to the Interpretation of Treaties', Sixty-eighth Session (2 May-10 June and 4 July-12 August 2016) UN Doc A/71/10 at 184-185; Vienna Convention on the Law of Treaties (VCLT) (adopted 23 May 1969, entered into force 27 January 1980) 1155 UNTS 331, Art 31(3)(b) and (c).

${ }^{15}$ ILC (n 14) 186.

${ }^{16}$ Case of Hirsi Jamaa and Others $v$ Italy, Application No 27765/09, Judgment of 23 February 2012, para 27.

${ }^{17}$ Case of Stummer v Austria, Application No 37452/02, Judgment of 7 July 2011, para 49.
} 
Labour, ${ }^{18}$ the European Social Charter, ${ }^{19}$ reports of the United Nations (UN) High Commissioner for Refugees ${ }^{20}$ and the Venice Commission. ${ }^{21}$ In doing so, the Court has demonstrated openness towards integrating rules of international law and international legal practice in the interpretation of the Convention.

This legal situation was clearly illustrated by the decision in Demir and Baykara in which the Court positioned the operation of the Convention within the existing system of international law and international sources. In defining the meaning of terms and notions in the text of the Convention, the Court clarified that it can and must rely on elements of international law beyond the Convention, which denote a continuous evolution of the terms and which demonstrate a 'common ground in modern societies'. ${ }^{22}$ It further stressed that the 'increasingly high standard being required in the area of the protection of human rights' necessitates 'greater firmness in assessing breaches of the fundamental values of democratic societies'. ${ }^{23}$ In Ziemele's terms, the decision is an example where the Court 'leaves itself a space for some creative thinking and adjudication in which various sources of international law can be helpful to adjudicate on a tendency which has not yet become a rule. ${ }^{24}$ Even further however, the Court indicates that various sources and rules of international law can be used as evidence of general legal practice that can be absorbed by an evolutive interpretation of the Convention and further the obligations of state parties. In this regard, the interpretation and protection of a right can be the result of practice developed among states within and outside the Convention and can be manifested through constitutional law and domestic

\footnotetext{
${ }^{18}$ Case of Siliadin v France, Application No 73316/01, Judgment of 26 July 2005, para 51.

${ }^{19}$ Sørensen and Rasmussen v Denmark, Application No 52562/99 and 52620/99, Judgment of 11 January 2006, para 35.

${ }^{20}$ Case of Abdolkhani and Karimnia v Turkey, Application No 30471/08, Judgment of 22 September 2009, para 46.

${ }^{21}$ Case of Sitaropoulos and Giakoumopoulos v Greece, Application No 42202/07, Judgment of 16 March 2012, para 22.

${ }^{22}$ Case of Demir and Baykara v Turkey, Application No 34503/97, Judgment of 12 November 2008, para 86; See also: Case of National Union of Rail, Maritime and Transport Workers $v$ The United Kingdom, Application No 31045, Judgment of 8 April 2014, para 76.

${ }_{23}^{23}$ Demir and Baykara (n 22) para 146.

${ }^{24}$ Ineta Ziemele, 'Customary International Law in the Case Law of the European Court of Human Rights' (2013) 12 The Method, The Law and Practice of International Courts and Tribunals 243, 246.
} 
legislation as well as international legal practice. ${ }^{25}$ By absorbing such practice into the interpretation of the Convention, the Court exercises its authority to identify and enforce them as legally binding elements that should be considered as capable of giving rise to custom. In relation to the right to property, it will be shown in sections III and IV below that the dynamic interpretation of the A1-P1 has permitted the ECtHR to expand the scope of protection and, by relying on domestic and international legal instruments, to bring it in line with common standards that bind European states. The question then arises whether opinio juris can be drawn from the ECHR. This is especially pertinent because the Court does not characterise European-wide consensus or international legal practice as binding, but uses it as 'indicative' and 'persuasive' evidence in interpreting the Convention. ${ }^{26}$

In the case of the United Communist Party of Turkey $v$ Turkey the Court achieved a major breakthrough by demonstrating that evidence of opinio juris can be ascertained through a dynamic interpretation of the Convention. The ECtHR established that contracting states have a legal obligation to have a democratic system of governance, and held that democracy is the only political model that is compatible with the Convention. Democratic governance underpins the effective implementation and further realisation of the rights under the Convention and binds state parties inter $\mathrm{se}^{27}$ It follows from this that if a state does not establish and maintain a democratic system, then it is in breach of its obligations under the Convention. Moreover, the Court highlighted that the implementation of democratic governance in the area of the Council of Europe, rests on a certain degree of common understanding and homogeneity in the values shared among the contracting parties and in the

\footnotetext{
${ }^{25}$ Francesco Francioni, 'Customary International Law and the European Convention on Human Rights' (1999) IX The Italian Yearbook of International Law 11, 21.

${ }^{26}$ Luzius Wildhaber, Arnaldur Hjartarson and Stephen Donnelly, 'No Consensus on Consensus? The Practice of the European Court of Human Rights' (2013) 33 Human Rights Law Journal 248, 256.

27 'Democracy is without doubt a fundamental feature of the European public order... That is apparent, firstly, from the Preamble to the Convention, which establishes a very clear connection between the Convention and democracy by stating that the maintenance and further realisation of human rights and fundamental freedoms are best ensured on the one hand by an effective political democracy and on the other by a common understanding and observance of human rights... Democracy thus appears to be the only political model contemplated by the Convention and, accordingly, the only one compatible with it.' Case of United Communist Party of Turkey and Others v Turkey, Application No 133/1996/752/951, Judgment of 30 January 1998, para 45.
} 
effective observance of human rights. Despite the undeniably pluralistic character of the European public order, the decision acknowledged that the promotion of human rights is grounded on the commitment of constitutional legal systems to democracy and the rule of law. As 'a fundamental feature of the European public order', ${ }^{28}$ only democracy can guarantee a comprehensive system of human rights and freedoms. From the absolute manner of formulating the link between democracy and the Convention and the reiteration of the common democratic principles of states, the presumption is raised that a psychological element of conviction on the existence of a legal obligation to introduce and maintain a democratic system of governance has taken place in Europe. ${ }^{29}$ That way, the reasoning of the Court can be taken as identification of opinio juris that contributes to the crystallisation of the principle of democratic governance as regional custom in Europe.

Elements of opinio juris can also develop from the implementation and supervision mechanisms of the Council of Europe which are sufficiently strong to give rise to a belief on the existence of a legal obligation. The Committee of Ministers, which under Article 46 of the ECHR has the competence to oversee the execution of judgments and to supervise the implementation of general measures by the contracting parties, has a significant role within a collective enforcement framework aimed to induce fuller observance of the Convention standards. Recently, the Court considered that applications relating to the non-execution of pilot judgments can be transmitted directly to the Committee of Ministers in order to improve the effectiveness of the human rights system. ${ }^{30}$ In another instance, the Committee initiated infringement proceedings against Azerbaijan for the failure to implement the Court's judgment in the Mammadov case. ${ }^{31}$ In this context, the persisting execution problems of the

\footnotetext{
${ }^{28} \mathrm{Ibid}$, para 45.

${ }^{29}$ Ibid, para 235-46; See: Stephen Wheatley, 'Democracy in International Law: A European Perspective' (2002) 51 International Comparative Law Quarterly 225.

${ }^{30}$ Case of Burmych and Others v Ukraine, Application Nos 46852/13 et al, Judgment of 12 October 2017.

${ }^{31}$ Committee of Ministers Interim Resolution, 'Execution of the Judgment of the European Court of Human Rights' CM/ResDH (2017) 429, 5 December 2017; Case of Mammadov (Jalaloglu) v Azerbaijan, Application No 34445/04, Judgment of 11 January 2007.
} 
Court judgments are not capable of reducing the contribution of these monitoring methods to the emergence of elements of customary law.

Moreover, given the subsidiary character of the supervisory measures established by the Convention, states have assumed the obligation to ensure the full and effective enforcement of the Court's judgments. ${ }^{32}$ Despite the apparent aim of the principle of subsidiarity to lead to greater deference by the Court to the contracting parties, the principle is indicative of the shared responsibility between the Council of Europe organs and national authorities to ensure the effective implementation of the Convention. In the case of domestic actors, this primarily involves changes in their legislative, judicial and administrative practices in order to meet their obligations. In addition, even though the Convention itself cannot serve as conclusive evidence of opinio juris, it is relevant that the Court has absorbed domestic and international obligations of contracting parties into the provisions of the ECHR. In reading extra-treaty obligations into the Convention, it takes into account and enforces the common expectations and conviction that these rules are legally binding on states. These enforcement and monitoring functions demonstrate a combination of mechanisms to secure compliance with regional obligations 'enmeshed' with international norms and domestic structures that can be taken as generating opinio juris.

In relation to the right to property, dynamic interpretation underpins the relevant jurisprudence of the Court. The ECtHR adduces obligations that go beyond the text of the Convention in order to reflect common standards that evolve among the state parties under domestic and international law. In particular, three key aspects in the case law on property rights demonstrate how the Court has developed the scope of A1-P1 through dynamic interpretation in order to provide practical and effective protection. First, it has recognised

\footnotetext{
${ }^{32}$ High-level Conference on the 'Implementation of the European Convention on Human Rights, our Shared Responsibility' Brussels Declaration, 27 March 2015.
} 
that the right should be considered an autonomous concept, in that, its meaning should be determined independently of the content possessed by an equivalent concept under national law. ${ }^{33}$ Second, it has introduced an obligation to pay full or partial compensation following a violation of the right to property. ${ }^{34}$ Third, it has expanded substantive and procedural requirements of the right and has linked them to wider interests of achieving good governance and preserving peace. ${ }^{35}$ In relation to all three elements, the Court integrates the developing practice of states, as identified from domestic legislation and international law, in order to interpret the content of the right to property and to feed back these evolving standards into the obligations under the Convention.

In light of the above discussion, it becomes clear that the Strasbourg system is capable of contributing to the development of regional customary law. While the ECHR offers strong evidence, it is not the only relevant source and sole basis for determining the right to property as regional custom. The practice of regional institutions and domestic constitutions confirm and contribute to the development of the rule. They provide external instances of practice that confirm the protection of the right to property. The discussion in section IV returns to this issue and highlights different examples of regional practice accepted as law. The next section provides an analysis of the content and scope of the right to property in order to provide a detailed elaboration of its evolution.

\section{On the Content of the Right to Property}

A central element of the jurisprudence of the ECtHR is that the autonomous nature of the right to property has allowed the Court to present, expand and substantiate the right from a potentially limited understanding under national law by encompassing private law notions of

\footnotetext{
${ }^{33}$ Case of Beyeler v Italy, Application No 33202/96, Judgment of 5 January 2000, para 100.

${ }^{34}$ Case of Kozacioğlu v Turkey, Application No 2334/03, Judgment of 19 February 2009, para 34.

${ }^{35}$ See analysis infra section III.
} 
possessions and ownership, and recognising legal persons as right-holders. ${ }^{36}$ The Court has clarified that the key term 'possessions' 'is in substance guaranteeing the right to property ${ }^{, 37}$ 'which is not limited to ownership of physical goods and is independent from the formal classification in domestic law: certain other rights and interests constituting assets can also be regarded as "property rights", and thus as "possessions" for the purposes of this provision., 38 Possessions have been determined by the Court to include not only ownership of immovables, ${ }^{39}$ but also ownership of shares, ${ }^{40}$ entitlements to pension ${ }^{41}$ and rent, ${ }^{42}$ as well as rights arising from running an enterprise. ${ }^{43}$ Claims to restitution of property ${ }^{44}$ and to compensation under tort law ${ }^{45}$ may also amount to possessions if they are sufficiently established to create legitimate expectations that the claims will be realised or if they are based on judicial decisions. $^{46}$

Moreover, the recognition and enforcement of the human right to property has permitted the ECtHR to expand the right beyond cases of expropriation to circumstances that pertain to social security. By providing a broad interpretation to the scope of the right, the Court has substantiated and enforced social benefits, such as housing assistance, ${ }^{47}$ entitlement to emergency assistance ${ }^{48}$ and disability benefits, ${ }^{49}$ in the European public order. Following this brief description of the meaning of the right to property under the ECHR, the necessary components for its protection will be examined in turn.

\footnotetext{
${ }^{36}$ Jan H Dalhuisen, 'Legal Orders and Their Manifestation: The Operation of the International Commercial and Financial Legal Order and Its Lex Mercatoria’ (2006) 24 Berkley Journal of International Law 129,141.

${ }^{37}$ Case of Marckx v Belgium, Application No 6833/74, Judgment of 13 June 1979, para 63.

${ }^{38}$ Beyeler (n 33).

${ }^{39}$ Case of the Holy Monasteries v Greece, Application No 13092/87 and 13984/88, Judgment of 9 December 1994.

${ }^{40}$ Case of Brameleid \& Malmström $v$ Sweden, Applications Nos 8588/79 and 8589/79, Commission decision of 12 October 1982.

${ }^{41}$ Case of Stec and others $v$ the United Kingdom, Applications Nos 65731/01 and 65900/01, Judgment of 12 April 2006.

${ }^{42}$ Case of Lindheim and others $v$ Norway, Applications Nos 13221/08 and 2139/10, Judgment of 12 June 2012.

${ }^{43}$ Case of Iatridis v Greece, Application No 31107/96, Judgment of 25 March 1999.

${ }^{44}$ Case of Malhous $v$ Czech Republic, Application No 33071/96, Judgment of 12 July 2001.

${ }^{45}$ Case of Pressos Compania Naviera, SA and others v Belgium Application No 17849/91, Judgment of 20 November 1995.

${ }^{46}$ Case of Stran Greek Refineries and Stratis Andreadis v Greece, Application No 13427/87, Judgment of 9 December 1994.

${ }^{47}$ More recently, Case of Vrountou v Cyrpus, Application No 33631/06 Judgment of 13 October 2015; See in general: Case of Stummer v Austria, Application No 37452/02, Judgment of 7 July 2011; Case of Andrejeva v Latvia Application No 55707/00, Judgment of 18 February 2009.

${ }^{48}$ Case of Gaygusuz v. Austria, Application No 17371/90, Judgment of 16 Sept 1996, para 39; Case of Stec v UK (n 41) paras $53-54$.

${ }^{49}$ Case of Béláné Nagy v Republic of Hungary, Application No 53080/13, Judgment of 13 December 2016.
} 


\section{Compensation in Cases of Interference with the Right to Property owned by Nationals:}

\section{the Right to Property and Good Governance}

Under the ECHR, interference with the right to property is permitted as long as the measures adopted by the state are compatible with the law, for a general or public purpose and proportional. Regarding the potential conflicts that arise between the pursuit of public interest by domestic authorities and the proper protection of the right to property, the Court has been creative in employing interpretive devices to resolve them on a case-by-case basis. Notably, it uses the principles of effectiveness and good governance for that purpose. ${ }^{50}$

The principle of effective protection requires the payment of compensation that strikes a 'fair balance, ${ }^{51}$ between the public interest of the community and the requirements for the protection of the right, so that the claimant does not bear an individual and excessive burden. ${ }^{52}$ As acknowledged by the ECtHR, the protection to the right to property under the Convention would otherwise be 'largely illusory and ineffective' ${ }^{53}$ Importantly, the standard of compensation for violations of the right to property is calculated on the basis of the wellestablished principle of restitutio in integrum. This involves the payment of damages in order to place the injured party, as far as possible, in the position in which he or she would have been had the unlawful conduct not taken place.

\footnotetext{
${ }^{50} \mathrm{Cf}$ for a discussion of the principles see: Steven Greer, 'The Margin of Appreciation: Interpretation and Discretion under the European Convention on Human Rights' (Council of Europe Publishing, 2000) 18-19, online: $<$ http://www.echr.coe.int/LibraryDocs/DG2/HRFILES/DG2-EN-HRFILES-17(2000).pdf>; See also: Ingrid Leijten, 'Social Security as a Human Rights Issue in Europe - Ramaer and Van Willigen and the Development of Property Protection and Non-Discrimination under the ECHR (2013) 73 Zeitschrift für Ausländisches Öffentliches Recht und Völkerrecht 177.

${ }^{51}$ Case of Sporrong and Lönnroth $v$ Sweden, Applications Nos 7151/75 and 7152/75, Judgment of 23 September 1982, para 69.

${ }^{52}$ See in general: Sergey Ripinsky and Kevin Williams, Damages in International Investment Law (British Institute of International and Comparative Law, 2008) 80-83.

${ }^{53}$ Case of James and others $v$ The United Kingdom, Application No 8793/79, Judgment of 21 February 1986, para 54.
} 
Inevitably, there is a distinction in relation to lawful and unlawful dispossessions within the scope of the ECHR. ${ }^{54}$ In the latter case, it is clear that the "inherent illegality, ${ }^{55}$ of a taking entails the payment of damages equal to the full market value of the property. In instances where the dispossession is lawful, that is, when it is according to the law and serves a public interest, the amount payable must only be 'reasonably related' to the value of the property and the circumstances of the taking. It follows from this that specific cases of lawful expropriation in the public interest, such as 'distinct expropriation of land with a view to building a road or for other purposes', ${ }^{56}$ may still require full compensation to achieve a 'fair balance' and not to impose a disproportionate burden on the claimant. However, the Court has identified instances where the pursuit of a legitimate objective can be compensated with an amount less than the full value. ${ }^{57}$ This approach was followed in the case of The Former King of Greece $v$ Greece. ${ }^{58}$ The ECtHR noticed that where the taking of property was resorted to in order to complete fundamental changes in the constitutional system of the state, such as the transition from a monarchy to a republic, then the payment of less than the full value of the property may be called for. ${ }^{59}$ The determining factor here is that reimbursement for the dispossession takes place in a broader context of political transformation and economic restructuring in the contracting state, and the Court defers to the national authorities to determine which actions are in the public interest.

In turn, the principle of good governance permits the ECtHR to impose procedural constraints on the way national authorities pursue public interest so that they do not violate

\footnotetext{
${ }^{54}$ Case of the Former King of Greece and Others v Greece, Application No 25701/94, Judgment of 28 November 2002, paras 73-79; See: Case of OAO Neftyanaya Kompaniya Yukos v Russia, Application No 14902/04, Judgment of 31 July 2014 (just satisfaction); For cases beyond the ECHR see, among others: Factory at Chorzow (Germany v Poland), 1926 PtC of Arbitration (ser A) No 7 (1925) para 125, which has been cited by the ECtHR in Case of Papamichalopoulos and Others $v$ Greece (Article 50), Application No 14556/89, Judgment of 31 October 1995, para 36; Amoco International Finance Corporation v Iran (1987) 15 Iran-US CTR 189, cited in Case of Guiso-Gallisay v Italy, Application No 58858/00, Judgment of 22 December 2009, para 50.

${ }_{55}^{5}$ Former King of Greece (n 54) para 78.

${ }^{56}$ Case of Scordino v Italy (No 1), Application No 36813/97, Judgment of 29 March 2006, para 96.

${ }_{58}^{57}$ James $v$ UK (n 53).

${ }_{58}^{58}$ Former King of Greece v Greece (n 54).

${ }^{59} \mathrm{Ibid}$, para 78 .
} 
private property. ${ }^{60}$ For example, the principle ensures that the actions of legislative and administrative bodies must be predictable and consistent in order to facilitate the individual to reasonably foresee the impact that such actions may entail ${ }^{61}$ and, thus, to comply with the rule of law. The Court in Păduraru clarified that public authorities must 'act in good time, in an appropriate manner and with utmost consistency ${ }^{, 62}$ and any domestic measure affecting private property 'must be implemented with reasonable clarity and coherence, in order to avoid, in so far as possible, legal uncertainty and ambiguity for the legal persons concerned by the measures to implement it. ${ }^{, 63}$

In light of this, the assessment of the public interest is a critical factor in the jurisprudence of the ECtHR. The Court affords a wide margin of appreciation and shows deference to national authorities in determining the regulation of property in the particular social, political and economic circumstances of the domestic order. As Berman puts it, the discretion provided to domestic polities provides 'some room to maneuver in implementing ECHR decisions in order to accommodate local variation. ${ }^{, 64}$ According to the author, the exercise of deference should be seen as a pluralist approach that clearly displays the multilevel interaction and special engagement taking place between the rules of the Convention and national law. This is so because the interpretation of the Court enables oversight over the appropriate implementation of the right to property that meets the standards of the Convention and at the same time accommodates complex social concerns of the state. The approach might be slow in developing a set of detailed principles that govern the right, nevertheless it provides room for a degree of 'responsivity" ${ }^{65}$ among the different legal orders. In this sense,

\footnotetext{
${ }^{60}$ Greer (n 50) 24.

${ }^{61} \mathrm{Ibid}, 16$.

${ }^{62}$ Case of Păduraru v Romania, Application No 63252/00, Judgment of 1 December 2005, para 91; See also: Beyeler (n 33) para 120; For the use of the term see Case of Moskal v Poland, Application No 10373/05, Judgment of 15 September 2009, paras 51 and $72-76$.

${ }^{63}$ Păduraru (n 62) para 92.

${ }^{64}$ Paul Schiff Berman, Global Legal Pluralism: A Jurisprudence of Law Beyond Borders (CUP, 2012) 161.

${ }^{65}$ Lars Viellechner, 'Responsive Legal Pluralism: The Emergence of Transnational Conflicts Law' (2015) 6 Transnational Legal Theory 312.
} 
the principles of effectiveness and good governance, which underpin the reasoning of the Court and steer its interpretation of A1-P1, allow for the expansion and deepening of commitment to the right to property that is conducive to the rule of law and the stability of legal and economic relations to which individuals are entitled in a democratic society. As illustrated above, the formulation of the link between the right and the principle of good governance in Păduraru offers a developing framework of reference and protection for the right from abuse of power under the Convention while respecting national particularities. It also provides a clear manifestation of how potential conflicts are resolved by the implementation of procedural principles. By resorting to the principles of effectiveness and good governance, the ECtHR achieves to channel differences and to manage coordination between the Convention standards on property rights and domestic concerns of public interest in a common social space in Europe.

Significantly, the strengthening of the obligation to respect and promote private property in Europe has also been achieved by the CJEU, which also expresses a pluralist conception of the right. The CJEU places it in the wider European legal context by observing and taking into account a variety of overlapping sources -the common constitutional traditions of member states, consistent legislative practices of domestic institutions and A1-P1 of the ECHR- ${ }^{66}$ when it examines its content and standard of protection. Acknowledging that the right to property constitutes a general principle of EU law stemming from the common constitutional traditions of member states, the CJEU relies on the case law of the ECtHR to determine its content. In the EU legal order specifically, the human right to property has been supplemented with transnational economic freedoms, such as the freedom to pursue trade or professional activities and the freedom to conduct work. ${ }^{67}$ The interconnectedness between the right to property and economic freedoms has achieved the strengthening of transnational

\footnotetext{
${ }_{67}^{66}$ Case 44/79 Liselotte Hauer v Land Rheinland-Pfalz [1979] ECR 3727 paras 17-30.

${ }^{67}$ Ibid.
} 
economic relations and the integration of the internal market, given that it ensures that individuals are not excluded from the sphere of economic activities by the overstretch of arbitrary political power. ${ }^{68}$ Unlike the ECtHR, the CJEU does not order the payment of compensation when a violation is found, except when it deals with state liability cases or compensation is required by sectorial secondary EU law. However, it adopts the same approach based on a balancing assessment between the pursuit of a legitimate objective and the proportionality of the alleged interference. ${ }^{69}$

It transpires therefore that this interaction and accommodation among the legal orders of the ECHR, the EU and states, shapes a common normative basis and consistent judicial practice with respect to the right to property which leads to a workable multi-level system of protection of the right in Europe. The relevance of another legal order becomes apparent when the property rights of foreign nationals are considered. In this respect, international law must also be taken into account, as it substantiates the treatment of property owned by foreign investors and is acknowledged by and incorporated within the ECHR system. The section below turns to this issue.

\section{Full Compensation for Direct and Indirect Expropriation of Property belonging to}

\section{Foreign Nationals: the Right to Property and Transnational Economic Activities}

Crucially, the ECtHR has clarified that the standards of protection of property rights owned by nationals under the Convention are different from the rules on the treatment of foreignowned property under international law. The amount of compensation payable under the Convention and international law was raised in James $v$ UK. The applicants argued that the

\footnotetext{
${ }^{68}$ Achilles Skordas 'Völkerrechtsfreundlichkeit as Comity and the Disquiet of Neoformalism: a Response to Jan Klabbers' in Panos Koutrakos (ed), European Foreign Policy - Legal and Political Perspectives (Edward Elgar Publishing, 2011) 115, 133.

${ }^{69}$ Case 265/87 Hermann Schräder HS Kraftfutter GmbH \& Co KG v Hauptzollamt Gronau [1989] ECR 2237, paras 14-15; Case C-347/03 Regione Autonoma Friuli-Venezia Giulia and Agenzia Regionale per lo Sviluppo Rurale (ERSA) [2005] ECR I-3820, paras 119-20; Joined Cases C-402/05 P and C-415/05 P Yassin Abdullah Kadi and Al Barakaat International Foundation $v$ Council of the European Union and Commission of the European Communities [2008] ECR I-6351, paras 35560 .
} 
provision in A1-P1 referring to the 'general principles of international law' should be interpreted as entitling them to compensation that is prompt, adequate and effective. They asserted that this international legal requirement for the expropriation of property of foreign nationals should also be applied to nationals. ${ }^{70}$ The Court, however, rejected the applicants' position. It held that the inclusion of the phrase 'general principles of international law' ensures that non-nationals can directly resort to the Convention and enforce their rights on the basis of general principles of international law, but does not entitle the nationals of the state parties to the Convention to the international standard of compensation. Relying on the wording of the Convention and the travaux préparatoires, the Court concluded that the difference in the standard of treatment between nationals and foreigners is well-established and justified:

it has not been demonstrated that, since the entry into force of [A1-P1], State practice has developed to the point where it can be said that the parties to that instrument regard the reference therein to the general principles of international law as being applicable to the treatment accorded by them to their own nationals. The evidence adduced points distinctly in the opposite direction. ${ }^{71}$

Thus,

$[\mathrm{t}] \mathrm{o}$ begin with, non-nationals are more vulnerable to domestic legislation: unlike nationals, they will generally have played no part in the election or designation of its authors nor have been consulted on its adoption. Secondly, although a taking of property must always be effected in the public interest, different considerations may apply to nationals and nonnationals and there may well be legitimate reason for requiring nationals to bear a greater burden in the public interest than non-nationals. ${ }^{72}$

It transpires therefore that the international rules governing the treatment of property of

\footnotetext{
${ }^{70}$ James $v$ UK (n 53) para 58.

${ }^{71}$ Ibid para 65; See also: Case of Lithgow and Others $v$ The United Kingdom, Applications Nos 9006/80; 9262/81; 9263/81; 9265/81; 9266/81; 9313/81 and 9405/81, Judgment of 8 July 1986, paras 111-19.

${ }^{72}$ James $v$ UK (n 53) para 63.
} 
non-nationals and in particular foreign investors can be used to interpret the scope of A1-P1; they are binding on the parties to the Convention and are enforceable by the Court. While the ECtHR only referred to 'general principles of international law' without specifying the required standard of compensation under international law, it alluded to the fact that the standard is, and should be, higher than that applied to nationals under the Convention. In this way, it provided a progressive interpretation to the right to property under the Convention as exercised by foreign nationals. It remained open to the accommodation and application of international customary law on this issue and recognised the necessity for favourable treatment of foreign nationals that is independent of national law.

In doing so, the ECtHR links the human right to property exercised by foreign nationals under the Convention with the developed toolbox of international law on the protection of foreign investors that is conducive to the expansion of transnational economic activities. International legal practice has clarified the standard of compensation that is required for the protection of the right to property of foreign nationals following an event of direct or indirect expropriation by the host state. The Hull formula safeguarding the provision of 'prompt, adequate and effective' or 'full' compensation in cases of expropriation constitutes an indispensable aspect of the international minimum standard for the treatment of foreign nationals and, therefore, of customary international law. ${ }^{73}$ Yet, the link of the right to property under the Convention with transnational economic activities has not been fully explored in the jurisprudence of the ECtHR. Given that the normative space of the Court is delimited by the European human rights community that it represents, its jurisprudence has not moved beyond the statement in principle expressed in James. Nevertheless, by identifying the favourable

\footnotetext{
${ }^{73}$ US Secretary of State to Mexican Ambassador to the United States, 21 July 1938. The correspondence is reprinted in 'Mexico-United States: Expropriation by Mexico of Agrarian Properties Owned by American Citizens' (1938) 32 American Journal of International Law 181; See: Frank G Dawson and Burns H Weston, "Prompt, Adequate and Effective": A Universal Standard of Compensation?' (1962) 30 Fordham Law Review 727; Maurice H Mendelson, 'Compensation for Expropriation: The Case Law' (1985) 79 American Journal of International Law 414. For a more recent definition of the terms, see the 1992 World Bank Guidelines on the Treatment of Foreign Direct Investment, Art IV paras 3, 7 and 8.
} 
treatment of the property rights exercised by foreign nationals, it becomes clear that A1-P1 is not only relevant to territorially defined economic activities and good governance mechanisms within the contracting state. The protection of the right should be viewed as enhancing the capacity of individual citizens to pursue their personal self-development and to engage in economic activities across borders. ${ }^{74}$ Therefore, the right is a vehicle for strengthening integration and contributing to patterns of governance-building in the European public space.

Despite a clear trajectory in regional and international law to protect property owned by foreign nationals, there are instances that contradict the above practice. In the Barcelona Traction $^{75}$ judgment in 1970 and the more recent Diallo ${ }^{76}$ decision in 2010, the ICJ made the diagnosis that there is a lack of institutions in international law that could contribute to the interpretation of the status of the rights of foreign shareholders and the remedies to which they are entitled if their property rights are violated by the host state. ${ }^{77}$ The Court reiterated that the rules enshrined in investment treaties have a lex specialis character and no influence over the direction of customary international law. That way, it did not only refuse to ascertain the customary international rules in this area, but also neglected the fact that investment treaties and arbitral decisions can contribute to the development of custom. ${ }^{78}$ This conclusion was reached despite the fact that customary international obligations on the payment of compensation and the "rich coverage" ${ }^{, 79}$ of investment treaties were plainly relevant in Diallo. Therefore, it would have only been a small step for the ICJ to invoke the human right to

\footnotetext{
${ }^{74}$ Ernst-Ulrich Petersmann, 'Time for a United Nations 'Global Compact' for Integrating Human Rights into the Law of Worldwide Organizations: Lessons from European Integration' (2002) 13 European Journal of International Law 621, 62541.

${ }^{75}$ Case Concerning the Barcelona Traction, Light and Power Company Limited (New Application: 1962) (Belgium v Spain) (Second Phase) [1970] ICJ Rep 3.

${ }^{76}$ Case Concerning Ahmadou Sadio Diallo (Republic of Guinea v DRC) (Preliminary Objections) [2007] ICJ Rep 582; Case Concerning Ahmadou Sadio Diallo (Republic of Guinea v DRC) (Merits) [2010] ICJ Rep 639.

${ }^{77}$ The discussion of the judgements does not deal with the seminal findings of the Court in Barcelona Traction on the rules of nationality of companies and obligations erga omnes, and the acknowledgment of the relationship between diplomatic protection and international human rights in Diallo. These issues are widely considered as well-established rules and exceed the scope of this article.

${ }^{78}$ See: Wood (n 8).

${ }^{79}$ Diallo (Merits) (n 76) Joint Dissenting Opinion of Judges Al-Khasawneh and Yusuf 65, 73-74.
} 
property, including the right to own shares, under the doctrine of diplomatic protection, taking into account the developments under regional human rights instruments, such as the ECHR and the American Convention on Human Rights. ${ }^{80}$ For example, Judge Gros in his Separate Opinion in Barcelona Traction ${ }^{81}$ and Judges Al-Khasawneh and Yusuf in their Joint Dissenting Opinion in Diallo ${ }^{82}$ took note of the significant developments to the right to property under European human rights law and argued that these should provide normative guidance to the ICJ.

Conversely, transnational investment tribunals have on numerous occasions cast little doubt that bilateral investment treaties (BITs) have contributed to the settlement of customary international law on the treatment of foreign investors by virtue of their vast numbers and nearly universal participation. ${ }^{83}$ Therefore, the two decisions of the ICJ have to be considered as a complete failure of the Court to take acknowledge the 'deep changes ${ }^{\text {, }}$ ' that have taken place in international investment law and to be responsive to the dynamic architecture of the transnational legal order. By maintaining a sovereigntist approach to international law, the ICJ failed to support emerging trends in investment and human rights law and missed an opportunity to redefine its role as 'catalyst of integration'. 85

The divergence between the approach of the ICJ and investment tribunals discloses the idiosyncratic and competing rationalities of safeguarding state sovereignty sustained by the

\footnotetext{
${ }^{80}$ The ICJ explained that the scope of diplomatic protection had been widened to include not only alleged violations of the minimum standard of treatment of aliens but also internationally guaranteed human rights. This part of the judgement marks an expansive and progressive approach on the part of ICJ, which so far had not placed rights of individuals protected by international human rights law at the centre of the doctrine of diplomatic protection. See Diallo (Preliminary Objections) (n 76) para 39. Following this line of reasoning, it is a particularly problematic aspect of the judgment that ICJ drew a distinction between human rights of individuals and property rights of shareholders and did not recognise the latter as part of the human right to property.

${ }^{81}$ Barcelona Traction (n 75) Separate Opinion of Judge Gros para 12.

${ }^{82}$ Joint Dissenting Opinion of Judges Al-Khasawneh and Yusuf (n 79).

${ }^{83}$ Mondev International Ltd $v$ United States of America, ICSID Case No ARB (AF) 99/2, Award of 11 October 2002 para 48 ; See: Jose E Alvarez, 'The Development and Expansion of Bilateral Investment Treaties' (1992) 86 ASIL Proceedings 532; Andreas Lowenfeld, 'Investment Agreements and International Law' (2003) 42 Columbia Journal of Transnational Law 123. ${ }^{84}$ Alain Pellet, 'The Case Law of the ICJ in Investment Arbitration (2013) 28 ICSID Review 223, 226.

${ }^{85}$ Achilles Skordas, 'ICJ: Guardian of Sovereignty or Catalyst for Integration?' (2002) 8 International Legal Theory 49; See: Steffen Hindelang, 'Bilateral Investment Treaties, Custom and a Healthy Investment Climate' (2004) 5 Journal of World Investment \& Trade 789.
} 
former, on the one hand, and protecting private property and market freedoms held by the latter, on the other. Nonetheless, this does not necessarily destabilise the development of transnational standards on property rights, either through investment treaties, regional human rights courts or custom. The implications of the ICJ judgments should be confined within the scope of the doctrine of diplomatic protection, ${ }^{86}$ and are rectified by the emergence of transnational mechanisms to deal with the legal protection of the property of foreign nationals and the evolution of relevant legal rules. As evidenced by international investment and regional human rights law, individuals have gained direct access to judicial bodies in order to assert their right to property and dispute resolution mechanisms in these areas have contributed to the expansion and enforcement of the right at the transnational level.

Moreover, the two approaches depict at least a thin normative compatibility, albeit weak, which serves to safeguard the protection of private property under international law. In the case of the ICJ for example, the international minimum standard on the treatment of foreign nationals prevents the Court's rationality of protecting sovereignty from overtaking and dominating over all aspects of transnational economic activity. By providing legal guarantees against arbitrary interference with private property, even if limited to the category of cases where the direct rights of shareholders have been violated, the Court is able to recognise a minimum degree of protection of property rights. This divergence does not, at least, have a regressive impact on the development of the law and does not hinder the consideration of the same subject matter by transnational tribunals and the ECtHR more convincingly. ${ }^{87}$

Overall therefore, the influence of inconsistent international legal practice on the development of the right to property in Europe should not be overestimated, given that the

\footnotetext{
${ }^{86}$ Camuzzi International SA v Argentina (Jurisdiction) ICSID Case No ARB/03/2, 11 May 2005, para 141; See: Azurix v Argentina (Jurisdiction) ICSID Case No ARB/01/12, 8 December 2003, para 70-2; GAMI Investments Inc v The Government of the United Mexican States (UNCITRAL/NAFTA), Final Award of 15 November 2004, para 29-30.

${ }^{87}$ CMS Gas Transmission Company v Argentina, ICSID Case No ARB/01/8, Award of 17 July 2003, para 48.
} 
robust enforcement and arbitration mechanisms under the ECHR and investment treaties prevent the erosion of protection standards. However, they highlight the importance of clarifying the content and status of the right in the region and beyond. The main advantage of recognising an autonomous obligation under regional customary law, as will be illustrated in section IV is that it is binding on states regardless of their participation in these legal instruments and irrespective of any contradictory international practices and of social functions that property acquires in domestic legal systems.

\section{The Right of IDPs to Restitution of Property or, where not possible, to receive}

Compensation: the Right to Property and the Restoration and Maintenance of

\section{International Peace}

The establishment of property restitution mechanisms to restore possessions lost by persons that have been displaced as a result of conflict, is another key element of the effective protection of property rights. To the extent that property rights contribute to the realisation of a human rights order and good governance, they should be interpreted in a manner that takes account of the global interest in the unobstructed deployment of economic activities beyond state borders. However, judicial and state practice at the European and international levels has also recognised that the protection of property rights is embedded in the process of restoration and maintenance of peace. With this in mind, both generally recognised international standards and the ECtHR case law are discussed in this section to demonstrate the link between the right to property and the preservation of peace.

International standards now recognise the right of refugees and IDPs to return to their 
properties or to receive compensation where this is not possible. ${ }^{88}$ They emanate from international human rights treaties, soft law instruments and 'best practices' for enforcing the right of returning persons to their properties and for establishing quasi-judicial transitional bodies to resolve property disputes. ${ }^{89}$ As Leckie demonstrates, these soft law standards have developed detailed and consistent requirements that are applicable to post-conflict settings and, collectively, they go some way forward towards recognising a bundle of 'housing, land and property' rights. ${ }^{90}$ Moreover, these rights have been articulated by the UN SubCommission on Human Rights in the 'Pinheiro Principles', which clarify the close relation of property restitution and post-conflict objectives, such as the protection of human rights and the rule of law. ${ }^{91}$ In addition, the UN General Assembly (GA) has reinforced standard-setting in this area by adopting principles for the provision of remedies for victims of human rights violations. According to the GA, the remedies that should be made available include the return of property and the right to prompt and effective compensation. ${ }^{92}$ In Europe in particular, the practice of post-conflict reconstruction by the EU and international actors such as the UN in the territories of Bosnia-Herzegovina and Kosovo has promoted the implementation of the right of refugees and IDPs to return to their homes. ${ }^{93}$

Restitution of property rights is also clearly supported by the case law of the ECtHR in relation to the situation of displaced persons in Cyprus. In the Court's opinion, A1-P1

\footnotetext{
${ }^{88}$ See for example: Universal Declaration of Human Rights 1948 Art 13(2); International Covenant on Civil and Political Rights 1966 Art 12; Francis M Deng, 'Guiding Principles on Internal Displacement' (1998) UN Doc E/CN.4/1998/53/Add.2; Paulo Sérgio Pinheiro, 'The Return of Refugees' or Displaced Persons' Property' (2002) UN Doc E/CN.4/Sub.2/2002/17, para 14 (Pinheiro Principles).

${ }^{89}$ Scott Leckie (ed), Housing, Land, and Property Rights in Post-Conflict United Nations and Other Peace Operations: A Comparative Survey and Proposal for Reform (CUP, 2008); Margaret Cordial and Knut Røsandhaug, Post-Conflict Property Restitution: the Approach in Kosovo and Lessons Learned for Future International Practice (Martinus Nijhoff, Publishers, 2009).

${ }^{90}$ Scott Leckie, 'United Nations Peace Operations and Housing, Land, and Property Rights in Post-Conflict Settings: from Neglect to Tentative Embrace' in Leckie (n 89) 3, 9.

${ }_{91}^{91}$ Pinheiro Principles (n 88) para 14.

${ }^{92}$ UNGA Res 60/147, 'Basic Principles and Guidelines on the Right to a Remedy and Reparation for Victims of Gross Violations of International Human Rights Law and Serious Violations of International Humanitarian Law' (2006) UN Doc A/RES/60/147, Principle IX, para 15, 19 and 20.

${ }^{93}$ See for example: UNMIK Regulation 2000/60, 'On Residential Property Claims and the Rules of Procedure and Evidence of the Housing and Property Directorate and the Housing and Property Claims Commission' UNMIK/REG/2000/60 (31 October 2000); Kai Eide, 'A Comprehensive Review of the Situation in Kosovo’ UN Doc S/2005/635.
} 
encompasses the right of IDPs to restitution of movable and immovable property. ${ }^{94}$ Importantly, this includes an obligation to establish an effective and accessible framework of redress for complaints regarding the loss of legal title or interference with the use and enjoyment of one's property. ${ }^{95}$ While the Court has expressed deep support for restitution as the primary remedy for the violation of property rights in post-conflict situations, it has also recognised that it is not the only available remedy ${ }^{96}$ and that in some situations the provision of compensation would be more appropriate. ${ }^{97}$ In Demopoulos in particular, it was explained that respect for the right does not require a 'blanket policy,98 of restitution if it could cause mass evictions. The Court accepted that, over a prolonged period of time during which the legal owners are not in possession of their properties, there can be an attenuation of the link between the holding of the legal title and the possession, use and enjoyment of the property. ${ }^{99}$ As a practical consequence, the nature of the available redress that can be regarded as fulfilling the requirement of the Convention may be other than full restitution. Therefore, domestic legislation and policy should take into account the rights of the current occupants of the properties and the particular context of each case for determining the form of redress, given that mass evictions of the current occupants could pose serious risks to security and stability in the territory. To that end, restitution might be a less appropriate remedy than the payment of compensation where the former leads to 'disproportionate new wrongs ${ }^{100}$ and compromises the peacebuilding process.

The interpretive path followed by the ECtHR has transformed the legal context of

\footnotetext{
${ }^{94}$ Case of Xenides-Arestis $v$ Turkey, Application No 46347/99, (Third Section Decision as to the Admissibility) 2 September 2004, para 73 .

95 Joined Cases of Takis Demopoulos and Others v Turkey, Application Nos 46113/99, 3843/02, 13751/02, 13466/03, 10200/04, 14163/04, 19993/04, 21819/04 (Grand Chamber Decision as to the Admissibility) 1 March 2010, para 127.

${ }^{96}$ See Case of Jantner v Slovakia, Application No 39050/97, Judgment of 4 March 2003, para 34; Case of Kopecký v Slovakia, Application No 44912/98, Judgment of 28 September 2004, para 25; Păduraru (n 62) para 89; Antoine Buyse, 'Lost and Regained? Restitution as a Remedy for Human Rights Violations in the Context of International Law' (2008) 68 Zeitschrift für Ausländisches Öffentliches Recht und Völkerrecht 129, 146.

${ }^{97}$ Demopoulos (n 95) paras 113-4.

${ }^{98} \mathrm{Ibid}$, para 117.

${ }^{99} \mathrm{Ibid}$, para 113

${ }^{100}$ Case of Pincová and Pinc v the Czech Republic, Application No 36548/97, Judgment of 5 November 2002, para 58.
} 
seeking remedies for the violation of property rights in post-conflict situations in the area of the Council of Europe in general and in Cyprus in particular. ${ }^{101}$ First, the Court has clarified that the laws passed by authorities of a de facto regime such as the Turkish Republic of Northern Cyprus (TRNC), which has not been recognised as a state by the international community, do not have the effect of changing the legal ownership of properties abandoned by IDPs. It follows from this that legal title to property remains with the persons who were displaced as a result of the 1974 conflict, as legal validity cannot be attributed to laws and decisions of the TRNC purporting to bring changes in the legal ownership of the properties. ${ }^{102}$ In this context therefore, it is the interference with the use and peaceful enjoyment of the property that constitutes the violation of A1-P1 rather than the loss of legal title. Second, decisions of the ECtHR have led to the creation of a redress mechanism, the Immovable Property Commission (IPC), to deal with claims of Greek Cypriots who lost possession of their properties in Northern Cyprus. ${ }^{103}$ Third, the Demopoulos judgment, by suggesting that the passage of time and the failure of the parties to the conflict to reach a political agreement has had a significant impact on the remedy available for the violation of property rights, ${ }^{104}$ explicitly elevated the potential conflict between the right to property of Greek Cypriot IDPs and the rights of current occupants of these properties as a legally relevant factor in determining the appropriate forms of redress. Moreover in 2010, the same year of the Court's decision, the Parliamentary Assembly of the Council of Europe had adopted resolution 1708 which specified the principles governing the payment of compensation for loss of property as a result of displacement. It emphasised that the provision of either restitution or compensation is a necessary precondition for the restoration of the rule of law, stability and peace and

\footnotetext{
${ }^{101}$ For a detailed account see: Nasia Hadjigeorgiou, 'Remedying Displacement in Frozen Conflicts: Lessons From the Case of Cyprus' (2016) 18 Cambridge Yearbook of European Legal Studies 152.

102 Loizidou (n 3) paras 46 and 63.

${ }^{103}$ The obligation to establish an effective property claims mechanism has been more recently confirmed in the context of Nagorno-Karabakh in Case of Sargsyan v Azerbaijan, Application No 40167/06, Judgment of 16 June 2015 , para 238 and Case of Chiragov and Others $v$ Armenia, Application No 13216/05, Judgment of 16 June 2015, para 199.

${ }^{104}$ Rhodri C Williams and Ayla Gürel, 'The European Court of Human Rights and the Cyprus Property Issue: Charting a Way Forward' Peace Research Institute Paper 1/2011, online: $<$ http://file.prio.no/publication files/Cyprus/Paper\%202011-

1\%20The \%20European $\% 20$ Court $\% 20$ of $\% 20$ Human $\% 20$ Rights $\% 20$ and $\% 20$ the $\% 20$ Cyprus $\% 20$ Property $\% 20$ Issue.pdf $>$.
} 
therefore integrated both remedies into broader programmes for the establishment of a human rights order. ${ }^{105}$

The Court has been criticised for taking a formalistic approach to reviewing the remedies provided by the IPC. Loucaides has claimed for example that the ECtHR has limited itself to the fact that the IPC offers restitution and compensation as available remedies to claimants, and has refrained from evaluating the effectiveness of these remedies. ${ }^{106}$ Nonetheless in a recent judgment in the Joannou case, ${ }^{107}$ the Court considered that the lack of effectiveness in the procedures followed by a body remedying violations of property rights resulting from conflict could, itself, constitute a breach of A1-P1. The ECtHR determined that the protracted length of the proceedings caused by the "passive attitude ${ }^{108}$ of the IPC in handling the applicant's claim to compensation led to a violation of the right to property. In particular, the failure of the IPC to act 'with coherence, diligence and expedition'109 and to scrutinise the conduct of the relevant TRNC authorities in overstepping time-limits and in improperly administering submitted documents contributed to the prolongation of the proceedings and undermined the efficacy of the remedies sought. ${ }^{110}$ The judgment draws a direct link between the protection of the right to property and the effectiveness of the property claims procedures by confirming that excessive delays in the administration of justice constitute a significant threat to the rule of law and can thus lead to a violation of A1-P1. ${ }^{111}$ Read together with the judgment in Păduraru, the Joannou decision clarifies that the standards of effectiveness and good governance apply not only to the conduct of national authorities interfering with private property in the public interest but also in remedying such interference. Inducing the

\footnotetext{
${ }^{105}$ Council of Europe Parliamentary Assembly, 'Solving Property Issues of Refugees and Internally Displaced Persons', Resolution 1708 (28 January 2010).

${ }^{106}$ Loukis G Loucaides, 'Is the European Court of Human Rights Still a Principled Court of Human Rights after the Demopoulos Case?' (2011) 24 Leiden Journal of International Law 435.

${ }^{107}$ Case of Joannou v Turkey, Application No 53249/14, Judgment of 12 December 2017.

${ }^{108}$ Ibid, para 97.

${ }^{109} \mathrm{Ibid}$, para 104.

${ }^{110}$ Ibid, paras $97-8$

${ }^{111} \mathrm{Ibid}$, para 96.
} 
commitment of relevant actors to act in accordance with such procedural guarantees and international legal standards increases the legitimacy of property claims mechanisms. That way, the judgments of the Court can make a major contribution to the development of a comprehensive system of governance in property relations in post- or frozen conflict situations and to a more or less productive relationship between domestic and international sources of authority that is conducive to restoring and maintaining international peace.

Furthermore, it should be mentioned that the Court has demonstrated full awareness of the political context surrounding the Demopoulos and Joannou cases. In both decisions, it is clear that the Court showed legal restraint in order not to substitute with its own judgment the long-term resolution of land and property rights in Cyprus, as this should be provided within a legal and institutional framework of a peace agreement. ${ }^{112}$ Instead, the impact of the Court's decisions has been to shape the parameters within which the parties can negotiate a solution on the restoration of property rights by excluding a blanket policy on either restitution or compensation. ${ }^{113}$ Either policy would constitute an obstacle to reaching a political agreement and pose a risk to stability in the territory and the region and, in this sense, the ECtHR situated the establishment of legal mechanisms for providing effective redress of property rights infringements within the process of peace preservation. It is further noteworthy that the reasoning of the Court in the Demopoulos judgment is in line with international standards ${ }^{114}$ and practice in relation to mechanisms remedying property violations in other conflicts in Europe, such as Bosnia and Herzegovina and Kosovo, and around the world, including East Timor and Iraq. It is evident from these peacebuilding operations that remedies consistently include a combination of restitution and compensation where the former would lead to mass evictions of peaceful occupants who are other than the legal owners of the properties.

\footnotetext{
112 Demopoulos (n 95) paras 85 and 96.

113 Rhodri and Gürel (n 104) 9.

114 The 'Pinheiro Principles', for example, make frequent references to the case law of the ECtHR and rely on its case law for guidance on the definition of legal terms, such as restitution, fair balance and arbitrary or unlawful expropriation. 
Therefore, the provision of such remedies constitutes an essential step towards the restoration of peace and towards achieving compatibility with human rights standards and the rule of law. ${ }^{115}$

Having discussed three of the main components of the right to property, it is clear that the Court has provided an evolutive interpretation and has developed its meaning and scope in order to ensure its effective protection. Despite the wide margin of appreciation that raises the presumption of a prima facie limited protection of the right, the Court has absorbed elements of state practice under domestic and international law and has offered a progressive interpretation. The right acquires strong normative value on the basis of its link with peace, good governance and the transnational economy, which can overcome inconsistencies and deference to national decision-making. The next section provides a detailed analysis of the nature of the obligation to protect the right in Europe.

\section{The Right to Property as Regional Custom in Europe}

Given the absence of a universal right to property, a universal custom could come into existence if the contribution of property rights — and economic freedoms more broadly— to an overall human rights order and the rule of law was not overlooked by international human rights instruments. Specifically, neither of the two 1966 Human Rights Covenants include express provisions for the right to property. The question then arises whether the robust legal mechanisms for the protection of the right to property in Europe have had a significant impact on shaping the right into a regional customary norm. It is argued here that the obligation to protect the right to property exists under regional customary law and includes the requirement that states introduce effective remedies in their domestic legal systems for its safeguard. As

\footnotetext{
${ }^{115}$ See for instance the inclusion of provisions on the treatment of private property of refugees and internally displaced persons in peacebuilding mandates as determined by the UN Security Council and other peacebuilding actors, General Framework Agreement for Peace in Bosnia and Herzegovina (14 December 1995) Annex 4, Art II and Annex 7; UNSC Res 1244 (1999) UN Doc S/RES/1244 paras 9(c) and 11(k); UNTAET Regulation 1999/1, 'On the Authority of the Transitional Administration in East Timor’ UNTAET/REG/1999/1 (27 November 1999) Section 3.
} 
will be illustrated, the customary rule is supported by treaty and non-treaty practice and opinio juris.

First, relevant practice that contributes to the development of custom emerges from the robust commitments that all three major organisations in the region have made: ${ }^{16}$ the Council of Europe with a clear legal obligation under the ECHR; the EU with a strong protection provided to the right to property under general principles of EU law and the Charter of Fundamental Rights of the EU (Charter); and the OSCE whose member states have made a commitment expressed at the Bonn Conference to the 'full recognition and protection of all types of property including private property, and the right of citizens to own and use them, [and to] the right to prompt, just and effective compensation in the event private property is taken for public use, ${ }^{117}$ as legal pillars of open market economies.

In light of this, there is little doubt that the ECHR, as an international treaty, and the Charter, as primary EU law incorporated in the Lisbon Treaty, are highly relevant for the formation of regional customary law. In terms of the OSCE, even though the document adopted at the Bonn Conference is non-binding, it 'reflect[s] the collective expression of the views ${ }^{118}$ of the signatory states. Therefore, it 'afford[s] an insight into the attitudes ${ }^{119}$ of these states in relation to the obligation to respect and to promote the right to property, and as such can provide evidence of state practice and opinio juris. According to the ILC, resolutions adopted by international organisations or at intergovernmental conferences provide evidence for establishing the existence and content of a customary rule, or contribute to its development. $^{120}$

\footnotetext{
${ }^{116}$ ILC, (n 7) Conclusion 4.

${ }^{117}$ Conference on Security and Co-operation in Europe, 'Document of the Bonn Conference on Economic Co-operation in Europe Convened in Accordance with the Relevant Provisions of the Concluding Document of the Vienna Meeting of the Conference on Security and Co-operation in Europe', online: <http://www.osce.org/eea/14081?download=true>.

${ }^{118}$ ILC, (n 7) 107.

119 Ibid.

${ }^{120}$ ILC, (n 7) Conclusion 6.
} 
Beyond the specific obligations adopted by regional organisations to promoting the protection of the right to property, relevant practice of the EU and the OSCE also emerges in the context of peacebuilding in the Balkans in the 1990 s and points in the same direction. ${ }^{121}$ The practice of states and regional organisations in implementing property restitution mechanisms and legislative reforms, as briefly identified in section III, has high normative value for the development of a customary obligation. This is so because these actors carried a 'predominant share ${ }^{122}$ in the costs and responsibilities for implementing effective property institutions under conditions safeguarding the restoration and maintenance of peace in the region.

Second, national laws and legislative acts also rank as evidence of state practice. ${ }^{123}$ Significantly, relevant practice that is widespread in Europe emerges with respect to national constitutional laws and also expands across a large number of states beyond the region. From a comparative perspective, the right to private property has been one of the most popular rights that is included in the majority of national constitutions around the world. A study conducted by Law and Versteeg demonstrated that, in 2006, 97 per cent of all national constitutions provided protection to the right to private property. ${ }^{124}$ In particular, a major moment of this trend in Europe has been the drafting of the constitution of the Russian Federation and, outside Europe, the amendments of the Chinese constitution. ${ }^{125}$ Both states

\footnotetext{
${ }^{121}$ European Commission and World Bank, 'Towards Stability and Prosperity: a Program for Reconstruction and Recovery in Kosovo' (1999) 3, online: <http://reliefweb.int/sites/reliefweb.int/files/resources/7DC58861A1B9C116852568

24006EE9FF-ecwb-kosovo.pdf >; See: OSCE, 'Eight Years After: Minority Returns and Housing and Property Restitution in Kosovo' Department of Human Rights and Rule of Law 2007 12, online: $<$ http://www.osce.org/kosovo/26322?download=true>; Rhodri C Williams, 'Post-Conflict Property Restitution and Refugee Return in Bosnia and Herzegovina: Implications for International Standard-Setting and Practice’ (2005) 37 Journal of International Law and Politics 441.

${ }^{122}$ Herman Meijers, 'How is International Law Made? - The Stages of Growth of International Law and the Use of its Customary Rules' (1978) 9 Netherlands YBIL 3, 7; See on the same point: Michael Wood, 'Second Report on Identification of Customary International Law' Sixty-sixth session (22 May 2014) UN Doc A/CN.4/672 at 36.

${ }^{123}$ ILC (n 7) Conclusion 6.

${ }^{124}$ David S Law and Mila Versteeg, 'The Evolution and Ideology of Global Constitutionalism' (2011) 99 California Law Review 1163, 1200. Alongside the right to property were, with an equally high percentage, civil and political rights, such as the freedom of religion and freedom of expression, and prohibition of arbitrary arrest and detention with 94 per cent.

${ }^{125}$ John G Sprankling, 'The Global Right to Property' (2014) 52 Columbia Journal of Transnational Law 464, 483-4; John G
} 
took steps to provide constitutional guarantees for private property in the end of the 1980 s and beginning of the 1990s. For example, the Russian constitution provides for 'the integrity of economic space, a free flow of goods, services and financial resources, support for competition, and the freedom of economic activity' and ensures equal protection of all forms of property. ${ }^{126}$ Accordingly, it protects the right to private property and guarantees the individual freedom to use one's property for entrepreneurial and economic activities. Moreover, it specifies that any interference with, or deprivation of, the right must be in accordance with a court decision and followed by the payment of compensation. ${ }^{127}$

In addition, European states, such as Germany, ${ }^{128}$ Italy, ${ }^{129}$ Norway, ${ }^{130}$ Belgium ${ }^{131}$ and Ireland $^{132}$ include the right to private property in their constitutions, whereas in the UK it applies by virtue of the Human Rights Act 1998. It is common practice that domestic constitutions contain provisions specifying that interference and deprivation of the right to property must be lawful and for a public purpose, ${ }^{133}$ whereas the requirement that expropriation must be followed by compensation is also constitutionally guaranteed. For example, the Basic Law of Germany provides that compensation must be paid taking into account the interests of those affected ${ }^{134}$ and the constitution of Russia declares that confiscation of property shall be carried out only 'on the proviso of preliminary and complete compensation. ${ }^{135}$ Other examples of constitutions which include such requirements are that of Norway, which calls for 'full compensation', ${ }^{136}$ while the Irish constitution unequivocally

\footnotetext{
Sprankling, 'The Emergence of International Property Law' (2012) 90 North Carolina Law Review 461.

${ }^{126}$ Constitution of the Russian Federation, Art 8.

127 Ibid, Art 35.

${ }^{128}$ Basic Law of the Federal Republic of Germany, Art 14.

${ }^{129}$ Constitution of the Italian Republic, Art 42.

${ }^{130}$ Constitution of the Kingdom of Norway, Art 105.

${ }^{131}$ The Belgian Constitution, Art 16.

${ }^{132}$ Constitution of Ireland, Art 43.

${ }^{133}$ Theo R G van Banning, The Human Right to Property (Intersentia, 2002) 144-45.

${ }^{134}$ Basic Law of Germany (n 128) Art 14.

${ }^{135}$ Constitution of Russia (n 126) Art 35.

${ }^{136}$ Constitution of Norway (n 130).
} 
guarantees that the state shall 'pass no law attempting to abolish the right of private ownership'. 137

Thus, the widespread state practice that emerges from national constitutional laws should be perceived as clear and mounting evidence of a regional customary rule. Crucially, the existence of this practice and its legal relevance has been repeatedly confirmed by the case law of the EU courts. ${ }^{138}$ Even though the CJEU has used this evidence in order to establish the right to property as a general principle of EU law, the existence of common constitutional laws in Europe should also be considered as a testament to ascertaining the development of regional custom.

Third, the judicial practice of the ECtHR and the CJEU should be considered as relevant evidence of state practice and opinio juris that needs to be examined. In light of this, the two courts enforce the right and contribute to the clarification and development of its content. While some doubt had been cast in the past over the relevance of decisions of international courts for the existence of customary rules, the ILC has clarified that judicial decisions of international and national courts on questions of international law constitute subsidiary means for the determination of customary international law. The Commission has added that they also rank as evidence of both state practice and opinio juris. ${ }^{139}$ Given the normative compatibility and interaction between the ECtHR and the CJEU in interpreting and enforcing the right to property, it should be considered that this judicial practice substantiates the emergence of regional custom. ${ }^{140}$ Moreover, the compliance of states with the relevant decisions and the supervision mechanisms of the Council of Europe and the EU provide

\footnotetext{
${ }^{137}$ Constitution of Ireland (n 132) Art 43(2).

${ }^{138}$ For the relevant case law see (n 66) and (n 69).

${ }^{139}$ ILC (n 7) Conclusions 6, 10 and 13; See also commentary to Conclusion 12.

${ }^{140}$ The approach of the CJEU with that of the ECtHR can be compared and contrasted with respect to the property rights in Northern Cyprus. However, the differences in their approaches concern the scope of the responsibilities of Turkey and the TRNC authorities rather that the content and application of property rights. Compare for example: Demopoulos (n 95) para 85 with Case C-420/07 Meletis Apostolides v David Charles Orams and Linda Elizabeth Orams [2009] ECR I-03571, para 51.
} 
further evidence of state practice in conformity with the right to property and the belief that states are legally bound by the obligation to protect the right.

In particular, the protection of the right to property constitutes a foundational aspect of the transnational economy. Its protection permeates transnational economic law, including the regulation of the internal market in the EU, and constitutes an essential part for the necessary development of transnational economic relations. Transnational standards for the guarantee of property rights are provided by a plurality of BITs, multilateral trade treaties and the case law of transnational investment tribunals. In the EU legal order, its fundamental and elementary character can become obvious if it is understood as the basis for realising and developing the economic freedoms which form the pillars of the internal market. For example, the EU courts in Hauer have linked it to the freedom to pursue trade ${ }^{141}$ and in Kadi have considered it as part of the 'mandatory rules of general international law, in which case an arbitrary deprivation of the right to property can be regarded as contrary to jus cogens. ${ }^{142}$ In the context of the ECHR, its recognition as a human right and its evolutive interpretation has allowed the Court to effectively formulate the right to property in the light of the broader objectives of the Convention, that is, the preservation of peace, democracy and the rule of law in the European public order and to also bring it in line with developments under transnational economic law. Therefore, a wider assessment of these interests confirms a comprehensive normative basis for the creation of custom and should be taken into account in determining the acceptance of the obligation to promote the right.

All in all, regional practice with a psychological element of conviction on the existence of a legal obligation to protect the right to property has clearly emerged. A degree of overlap of evidence for state practice and opinio juris in determining the existence of the regional

\footnotetext{
${ }^{141}$ Hauer (n 66).

${ }^{142}$ Case T-306/01, Yusuf and Al Barakaat International Foundation v Council and Commission [2005] ECR II- 3533, para 293.
} 
customary norm should not be seen as problematic. As Sir Michael Wood has clarified, the two elements might sometimes be 'closely entangled', ${ }^{143}$ and has not excluded the possibility that 'the same material may be used to ascertain practice and acceptance as law (opinio juris). ${ }^{, 144}$ Therefore, it can be assumed that states with stable, open market economies are bound by such a customary norm. The development of relevant rules under regional customary law signifies that a domestic socio-economic and legal framework should be in place with guarantees for property rights. The determination of such a customary norm has advantages also beyond the regional level by partially offsetting the restrictive approach of the ICJ in failing to take into account innovative state practice with regards to customary international law for the treatment of foreign investors and the right to property. A close reading of the ICJ's decisions in Barcelona Traction and Diallo, and their adverse impact on the particular individuals whose claims were espoused by the states of nationality, clearly illustrates the need to shed light on progressive forms of conduct and their effects on the evolution and interpretation of international rules. ${ }^{145}$ The obligation to grant effective safeguards for the protection of the right to property and for remedying interference creates further obligations and entitlements for states, most notably, to advance good governance structures, to respect the rule of law and to enhance the capacity of economic actors to participate in regional and transnational integration mechanisms. Economic systems based on deprivation of private property and economic freedoms would be, in this sense, incompatible with the relevant rules of the European public order, in particular, and norms of international law, in general.

\footnotetext{
${ }^{143}$ ILC, 'Formation and Evidence of Customary International Law' Sixty-eighth Session (6 May-7 June and 8 July-9 August 2013) UN Doc A/68/10, 101; See: Maurice H Mendelson, 'The Subjective Element in Customary International Law' (1996) 66 British Yearbook of International Law 177; Robert Kolb, 'Selected Problems in the Theory of Customary International Law’ (2003) 50 Netherlands International Law Review 119.

${ }^{144}$ ILC (n 7) commentary to Conclusion 3 para 8 which does not exclude that the same material may be used to ascertain practice and acceptance as law (opinio juris).'

${ }^{145}$ See in general: Richard B Lillich, 'Two Perspectives on the Barcelona Traction Case' (1971) 65 American Journal of International Law 522.
} 


\section{Conclusion}

The preceding analysis was prompted by the need to offer a better understanding of the legal principles and processes that provide protection to the right to property in the current architecture of the European public order. The ECtHR has been called for to enforce A1-P1 under conditions of major political and economic transformation in contracting states, situations surrounded by military conflict and in cases concerning state interference with private investments. Undeniably, in the pluralistic landscape of the Convention system the Court has been slow in identifying autonomous substantive standards of European-wide acceptance on the right to property. Nevertheless, it has made a significant contribution to addressing violations of private property by deploying interpretive mechanisms that integrate the right into processes of good governance, restoration of peace and facilitation of economic activities. The decentralised and multi-level structures that surround the regulation of the right allow for its sufficient adaptation into a shared public space in Europe. Moreover, it was the robust stance of the CJEU and the cautious, yet progressive, approach of the ECtHR that have led to a balanced commitment to economic freedoms and fundamental rights in Europe. In this context, the process of identifying and further developing protection standards could be accelerated if the right to property was viewed from a broader perspective of regional customary law. 